\title{
Pharmacotherapy of patients with mild persistent asthma: strategies and unresolved issues
}

\author{
Paolo Montuschi* \\ Department of Pharmacology, Faculty of Medicine, Catholic University of the Sacred Heart, Rome, Italy
}

\section{Edited by:}

Masakazu Ichinose, Wakayama

Medical University, Japan

Reviewed by:

Hiromasa Inoue, Kagoshima

University, Japan

Bruno Balbi, Fondazione Salvatore

Maugeri, Italy

*Correspondence:

Paolo Montuschi, Department of Pharmacology, Faculty of Medicine, Catholic University of the Sacred Heart, Largo Francesco Vito 1 ,

00168 Rome, Italy.

e-mail: pmontuschi@rm.unicatt.it
In studies comparing regular versus on-demand treatment for patients with mild persistent asthma, on-demand treatment seems to have a similar efficacy on clinical and functional outcomes, but it does not suppress chronic airway inflammation or airway hyper-responsiveness (AHR) associated with asthma. Data on the efficacy of a continuous treatment with inhaled corticosteroids (ICS) in preventing the progression of asthma are conflicting. There is the possibility that patients without a regular treatment with ICS may develop a more severe asthma associated with airway structural changes (remodeling) and a progressive loss of lung function. However, the possible clinical and functional consequences of persistent, not controlled, airway inflammation in patients with asthma have to be established. Assessment of asthma control should include inflammatory outcomes, such as fraction of exhaled nitric oxide and sputum eosinophil counts. Until the relationships between symptoms, lung function tests, AHR, airway inflammation, exacerbations, and airway remodeling are clarified, regular treatment seems to be generally more appropriate than on-demand treatment to warrant a greater control of asthma. Select subgroups of patients with mild asthma who are well controlled by regular treatment might adopt the on-demand treatment plan as an intermediate step toward the suspension of controller medication. The increasing evidence for heterogeneity of asthma, the growing emphasis on asthma subphenotypes, including molecular phenotypes identified by omics technologies, and their possible implications for different asthma severity and progression and therapeutic response, are changing the paradigm of treating patients with asthma only based on classification of their disease severity to a pharmacological strategy more focused on the individual asthmatic patient. Pharmacological treatment of asthma is going toward a personalized approach.

Keywords: asthma, airway inflammation, airway remodeling, inhaled corticosteroids, leukotriene receptor antagonists, non-invasive biomarkers, pharmacological treatment

\section{INTRODUCTION}

Asthma is characterized by chronic airway inflammation, which has a central pathophysiological role. Asthma control is the primary goal of pharmacological treatment of patients with asthma. The most effective drugs for asthma control are inhaled corticosteroids (ICS), which are effective anti-inflammatory drugs. Current guidelines recommend daily long-term controller medications in patients with persistent asthma (NAEPP National Asthma Education and Prevention Program: Expert Panel Report III, 2007; GINA Global Initiative for Asthma, 2010), including those with mild asthma, but some studies reported low rates of compliance with recommendations (Gupta and Weiss, 2009; KandaneRathnayake et al., 2009). Continuous treatment with ICS, alone or in combination, is required in patients with moderate persistent asthma and high-dose of ICS and/or oral corticosteroids in combination with other drugs are required in patients with severe asthma, but regular treatment of patients with mild persistent asthma is not often undertaken and some studies demonstrated that the effect of regular or on-demand treatment on functional end-points is equivalent (Boushey et al., 2005; Papi et al., 2007).
The need for continuous treatment with anti-inflammatory drugs, mainly ICS or leukotriene receptor antagonists (LTRA), in patients with mild persistent asthma is based on the fact that uncontrolled persistent airway inflammation might lead to airway remodeling with consequent decrease in lung function, worsen of asthma symptoms, and increase in asthma exacerbations and requirement of bronchodilators as rescue medications (Canonica, 2006; Murray, 2008). However, although plausible and likely, the link between persistent airway inflammation and airway remodeling has not been definitively established and their relationships are complex and not completely known (Bush, 2008). This is partially due to the limitations of predictive experimental models for airway remodeling, the difficulties of performing studies of airway remodeling in patients with asthma, which requires bronchoscopic and bioptic studies, the relative short duration of asthma clinical trials, the fact that assessment of anti-asthmatic drug efficacy is principally based on clinical and functional outcomes, and the relative lack of validated biomarkers or surrogate markers of airway inflammation. This review summarizes the pharmacological profiles of anti-asthmatic drugs indicated in patients with mild persistent 
asthma, presents new outcomes which reflect airway inflammation in randomized clinical trials, focuses on pharmacological strategies and unresolved issues related to treatment of patients with mild persistent asthma, and emphasizes the need for a tailored, personalized, approach to pharmacological treatment of patients with asthma.

\section{DRUGS FOR PATIENTS WITH MILD PERSISTENT ASTHMA}

Inhaled corticosteroids are the mainstay of asthma treatment. The preferred long-term controller drugs in patients with mild persistent asthma are ICS at low-doses (NAEPP National Asthma Education and Prevention Program: Expert Panel Report III, 2007; GINA Global Initiative for Asthma, 2010). Alternatively, LTRAs, mainly montelukast, can be used as mono-therapy in responders (NAEPP National Asthma Education and Prevention Program: Expert Panel Report III, 2007). Chromones are seldom prescribed (NAEPP National Asthma Education and Prevention Program: Expert Panel Report III, 2007; GINA Global Initiative for Asthma, 2010). This fact can be explained by the limited efficacy of chromones, but largely relies on total absence of interest of pharmaceutical industry in this class of drugs that unjustifiably affects their prescription. This is acknowledged by current guidelines that still recommend chromones as an alternative mono-therapy, particularly in children with mild persistent asthma in whom a non-steroid drug can be preferred (NAEPP National Asthma Education and Prevention Program: Expert Panel Report III, 2007). Theophylline is not generally administered as mono-therapy, but its combination with a low-dose of ICS can be more effective and safer than high-doses of ICS in patients with moderate persistent asthma (Evans et al., 1997).

\section{INHALED CORTICOSTEROIDS}

Inhaled corticosteroids currently available for asthma treatment include beclomethasone dipropionate, budesonide, ciclesonide, flunisolide, fluticasone propionate, mometasone furoate, and triamcinolone acetonide (NAEPP National Asthma Education and Prevention Program: Expert Panel Report III, 2007; GINA Global Initiative for Asthma, 2010). In patients with asthma, regular treatment with ICS improves all clinical, functional, and patient reported outcomes including improvement in lung function (Pauwels et al., 2003; O'Byrne et al., 2006), reduced frequency and severity of daytime asthma symptoms (Berger et al., 2009), decreased incidence of nighttime awakenings (Berger et al., 2009), decreased use of short-acting $\beta_{2}$-adrenergic agonists (SABAs) for symptom relief (Berger et al., 2009), improvement of the quality of life (Berger et al., 2009) and decreased risk of acute asthma exacerbations (Pauwels et al., 1997, 2003). In two doubleblind trials, early initiation of budesonide in mild persistent asthma was associated with reduced risk of severe asthma exacerbation and improved pulmonary function in comparison with placebo (Pauwels et al., 2003; O’Byrne et al., 2006). By reducing airway hyper-responsiveness (AHR), treatment with ICS may target the basic features of the airways that make them asthmatic, reducing their high sensitivity to all triggers of asthma. ICS suppress asthmatic inflammation with markers of airway inflammation, such as fraction of exhaled nitric oxide $\left(\mathrm{F}_{\mathrm{E}} \mathrm{NO}\right)$ concentrations (Kharitonov et al., 2002), and AHR (Sovijärvi et al., 2003) that return to baseline approximately 1 and 2 weeks after ICS withdrawal, respectively.

In the OPTIMA trial, patients with mild-to-moderate asthma treated with inhaled budesonide for 1 year had a reduced rate of severe exacerbations, days with asthma symptoms, and poorly controlled asthma days and nights in comparison with subjects treated with placebo (O’Byrne et al., 2001).

In the inhaled Steroid Treatment As Regular Therapy in early asthma (START) study, more than 7000 patients with new-onset asthma were treated with inhaled budesonide or placebo for 3 years and budesonide reduced the number of severe exacerbations and improved forced expriratory volume in one second $\left(\mathrm{FEV}_{1}\right)$ in comparison with placebo (Pauwels et al., 2003).

The efficacy of ICS has also been proved in infants and preschool-aged children ( $<5$ years of age) with recurrent wheezing or asthma, according to the results of a published metaanalysis (Castro-Rodriguez and Rodrigo, 2009). The study analyzed data from 29 randomized controlled trials comparing ICS versus placebo in 3592 children: patients who received ICS had significantly less wheezing/asthma exacerbations than those on placebo and this effect was independent of age, atopic condition, type of ICS used, and study duration. In addition, children treated with ICS had more clinical (change in symptom score) and functional [change in peak expiratory flow (PEF) and $\mathrm{FEV}_{1}$ from baseline] improvement than those on placebo (Castro-Rodriguez and Rodrigo, 2009).

Inhaled corticosteroids also reduce hospitalizations and mortality from asthma (Donahue et al., 1997; Suissa et al., 2000), but conflicting results have been reported on the effects of long-term treatment with ICS in preventing lung function decline in both adults (Pauwels et al., 2003; Boushey et al., 2005; O'Byrne et al., 2009) and children (Agertoft and Pedersen, 1994; Anonymous, 2000) with asthma. Part of this discrepancy could be due to differences in time and duration of asthma prior to starting therapeutic intervention with ICS (Agertoft and Pedersen, 1994; Anonymous, 2000). The ideal population to be targeted could be represented by patients with mild persistent asthma (Murray, 2008). Not all patients with asthma respond to ICS. Up to $35 \%$ of patients who do not experience improvements in $\mathrm{FEV}_{1}$ and/or AHR (Szefler et al., 2002) with ICS has been reported. Asthmatic phenotypes characterized by airway neutrophilic inflammation are less likely to respond to ICS than asthmatic patients with elevated eosinophilic inflammation. Airway neutrophilic inflammation is more typical, although not exclusive, of acute asthma exacerbation and severe asthma and less frequent in patients with mild persistent asthma (Wenzel, 2006; Gibson, 2009). In addition, patients with asthma who smoke may be relatively resistant to the effects of ICS at lowdose (Tomlinson et al., 2005; Lazarus et al., 2007). Finally, genetic differences may be responsible for steroid-resistance.

Treatment with ICS can have topical and systemic side effects. Weak or hoarse voice and candidiasis are the most frequent local effects (NAEPP National Asthma Education and Prevention Program: Expert Panel Report III, 2007; GINA Global Initiative for Asthma, 2010). The risk of developing adverse systemic effects from ICS is affected by several factors, including dose, drug delivery 
system used, and inter-individual differences in the response to the corticosteroids. Apart from bruising, long-term adverse systemic effects are not generally observed among adults taking low-to-medium doses, although effects on bone metabolism have been reported for doses as low as $400 \mu \mathrm{g}$ of beclomethasone per day or equivalent. At high-doses (usually $>1000 \mu \mathrm{g}$ of beclomethasone per day or equivalent), the risks of side effects increase. The most frequent of them are adrenal suppression, growth retardation in children, cataracts and elevated intraocular pressure. In older adults with asthma, ICS reduce bone mineral density after long-term, high-dose therapy (Irwin and Richardson, 2006). To minimize these side effects, strategies that can achieve asthma control without using high-doses of ICS and step down treatment to the lowest possible dose of ICS that maintains symptom control are desirable (Lemanske et al., 2001). In children, growth retardation is a concern but some data suggest that pre-adolescent school-age children who continue to receive long-term treatment with ICS ultimately reach their normal predicted height (Agertoft and Pedersen, 2000; Anonymous, 2000). ICS safety is affected by several factors (Derendorf et al., 2006). On-site activation in the lung, low oro-pharyngeal exposure and oral bioavailability, high protein binding and rapid systemic clearance improve safety of ICS (Colice, 2006; Derendorf et al., 2006). Prodrugs that are activated in the lungs but not in the oro-pharynx such as ciclesonide and beclomethasone and new formulations and devices that increase lung deposition can improve ICS safety (Colice, 2006; Derendorf et al., 2006).

\section{LEUKOTRIENE RECEPTOR ANTAGONISTS}

Selective cysteinyl (Cys) $\mathrm{LT}_{1}$ receptor antagonists, commonly known as LTRA, that have been approved for clinical use in asthma include montelukast and zafirlukast. Pranlukast is only marketed in Japan and other Asian countries. Zileuton is a 5-lipoxygenase (LO) inhibitor that has been approved for the prevention and continuous treatment of asthma in adults and children 12 years of age and older in the United Kingdom and USA. Zileuton it is not available in other countries and its use is limited by a modest but distinct incidence of hepatic enzyme elevation that is not observed with montelukast. Five-lipoxygenase activating protein (FLAP) inhibitors including 2190914 (AM-103) (Lorrain et al., 2009; Bain et al., 2010) and GSK-2190915 have entered phase II trials for the treatment of asthma (Sampson, 2009).

Montelukast is the most prescribed LTRA in Europe and North America. Zafirlukast was the first LTRA that was approved in Europe, is approved in adults and children with asthma 5 years of age and older, but it is not frequently prescribed due to possible food and drug interactions, and the twice daily administration regimen (Dahlen, 2006; Montuschi et al., 2007). Selective CysLT 1 receptor antagonists and 5-LO inhibitors appear to have similar efficacy in short-term treatment studies and challenge models, suggesting that most of the anti-asthmatic effects of anti-LTs are due to CysLT 1 antagonism (Dahlen, 2006).

Leukotriene receptor antagonists improve symptoms and lung function, and reduce exacerbation rate, the use of SABA, and airway and blood eosinophilia in adults and children with asthma of varying severity (Busse and Kraft, 2005; Dahlen, 2006; Montuschi et al., 2007; Peters-Golden and Henderson, 2007; Montuschi and
Peters-Golden, 2010). In patients with persistent asthma who are undertreated and remain symptomatic while taking SABA alone, LTRA provide a prompt improvement in asthma control, although low-dose ICS are generally more effective than LTRA as first-line maintenance treatment (Busse et al., 2001). In North America, mono-therapy with LTRA is a common therapeutic option for patients with mild persistent asthma (FitzGerald and Shahidi, 2010; Lougheed et al., 2010). However, ICS are generally preferred (NAEPP National Asthma Education and Prevention Program: Expert Panel Report III, 2007) due to their greater efficacy as firstline agents in both adults and children with asthma (Szefler et al., 2005). Nonetheless, LTRA can be used as controllers in patients who cannot tolerate ICS or prefer a non-steroid drug (FitzGerald and Shahidi, 2010; Lougheed et al., 2010).

Leukotriene receptor antagonists are effective in reducing early and late asthmatic responses induced by allergen inhalation in adults (Roquet et al., 1997; Leigh et al., 2002) and children (Phipatanakul et al., 2002), but these drugs are less effective than ICS in reducing allergen-induced AHR (Leigh et al., 2002).

In Europe, LTRA are indicated for preventing exercise-induced bronchoconstriction (Dahlen, 2006). Montelukast given at a dose of $10 \mathrm{mg}$ once daily protects against exercise-induced bronchoconstriction over a 12-week period in adults with asthma (Leff et al., 1998). This effect, observed as soon as $2 \mathrm{~h}$ after a single oral dose of montelukast $(10 \mathrm{mg}$ ), is maintained up to $24 \mathrm{~h}$ (Pearlman et al., 2006; Philip et al., 2007). Montelukast is more effective that salmeterol in the chronic treatment of exerciseinduced bronchoconstriction over a period of 8 weeks in adults with mild asthma (Villaran et al., 1999). LTRA are also effective in exercise-induced bronchoconstriction in children (Melo et al., 2003), although generally less effective than ICS in children with exercise-induced bronchoconstriction with persistent asthma (Grzelewski and Stelmach, 2009).

CysLT $_{1}$ receptor antagonism and 5-LO activity inhibition protect against the reduction in $\mathrm{FEV}_{1}$ in response to aspirin challenge (Dahlen, 2006) and improve asthma control in aspirin-sensitive patients (Dahlen et al., 1998, 2002).

Add-on therapy with LTRA improves asthma control (Bjermer et al., 2003; Price et al., 2003; Vaquerizo et al., 2003) and enables a reduction in the dose of ICS required to control asthma (Lofdahl et al., 1999). However, combination treatment with LTRA and ICS is generally less effective than combination of long-acting $\beta_{2}$-agonist (LABA) and ICS (Ducharme et al., 2006; Lemanske et al., 2010), The steroid-sparing effect reduces the risk of side effects caused by long-term administration of high-dose ICS (Price et al., 2003). There is a high degree of variability in the therapeutic response to LTRA in patients with asthma (Malmstrom et al., 1999; Vaquerizo et al., 2003; Szefler and Martin, 2010), but, to a lesser extent, this is also true for ICS.

Leukotriene receptor antagonists are generally safe and well tolerated. An association between LTRA and Churg-Strauss syndrome has been reported (Bibby et al., 2010). In most confirmed cases of Churg-Strauss syndrome reported, therapy with LTRA was a suspect medication (Bibby et al., 2010). In the majority of cases treated with a LTRA, Churg-Strauss syndrome could not be explained by ICS suspension or pre-existing Churg-Strauss syndrome (Bibby et al., 2010). 


\section{NEW OUTCOME MEASURES IN ASTHMA RANDOMIZED CLINICAL TRIALS: TOWARD A OMICS PROFILING}

Asthma control, the primary goal of pharmacological treatment, includes reduction of impairment and risk (NAEPP National Asthma Education and Prevention Program: Expert Panel Report III, 2007; Figure 1). Reduction of impairment implies prevention of chronic asthma symptoms, use of SABA equal or less than 2 days a week, maintenance of nearly normal lung function and normal activity (NAEPP National Asthma Education and Prevention Program: Expert Panel Report III, 2007); reduction of risk implies prevention of recurrent asthma exacerbations and decrease in lung function and optimal pharmacological therapy with minimal adverse effects (NAEPP National Asthma Education and Prevention Program: Expert Panel Report III, 2007). Conventional outcome measures used for assessing asthma control are symptoms, use of SABAs for quick symptom relief, limitation to normal activities due to asthma, lung function testing, AHR, and asthma exacerbations (NAEPP National Asthma Education and Prevention Program: Expert Panel Report III, 2007). Clinical trials for assessing efficacy of anti-asthmatic drugs are principally based on these conventional outcome measures. Although relevant and well-established outcome measures, symptoms, lung function testing, AHR, and asthma exacerbation rate do not reflect directly airway inflammation that is the main pathophysiological characteristic of asthma. This makes conventional outcome measures not ideal for assessing the direct effect of drugs for long-term asthma control that are primarily anti-inflammatory and for studying the relationships between persistent airway inflammation and airway remodeling. In other words, conventional outcomes are indirect measures of airway inflammation and lack sufficient sensitivity. Bronchoscopy and bronchial biopsy are the gold standard for assessing airway inflammation, but these techniques are invasive and not generally indicated in patients with asthma who are at greater risk for bronchospasm due to AHR. For these reasons, the identification and validation of non-invasive biomarkers of airway inflammation, to be used for the assessment of the asthmatic patients and for monitoring of pharmacological response, is

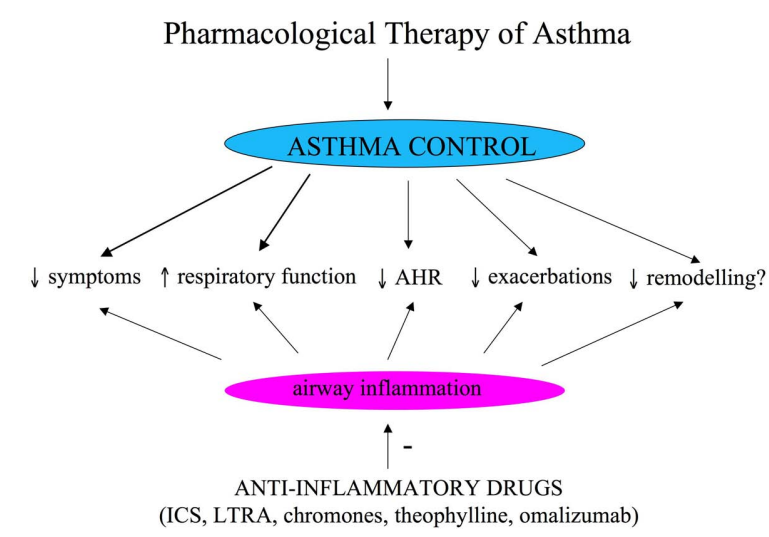

FIGURE 1 | Objectives of pharmacological treatment of asthma. ICS, inhaled corticosteroids; LTRA, leukotriene receptor antagonists. a priority in asthma research and, more generally, in respiratory research.

Non-invasive or semi-invasive techniques for assessing airway inflammation in patients with asthma have been validated or are under development (Tables 1 and 2). These include measurement of $\mathrm{F}_{\mathrm{E}} \mathrm{NO}$, measurement of eosinophils cell counts and biomolecules in sputum, measurement of biomolecules in exhaled breath condensate (EBC), and electronic nose (Figure 2).

\section{MEASUREMENT OF $\mathrm{F}_{\mathrm{E}} \mathrm{NO}$}

Measurement of $\mathrm{F}_{\mathrm{E}} \mathrm{NO}$, a completely non-invasive technique for assessing airway inflammation in patients with asthma, has been approved in the clinical setting (Silkoff et al., 2004). This technique is standardized, reproducible, and provides immediate results (Bates and Silkoff, 2003; Barnes et al., 2010). Portable, handheld, $\mathrm{F}_{\mathrm{E}} \mathrm{NO}$ analyzers that enable on-site sampling are available (Khalili et al., 2007; Menzies et al., 2007; Takalo et al., 2008).

Table 1 | Non-invasive monitoring of airway inflammation: current techniques.

\begin{tabular}{|c|c|}
\hline Technique & Characteristics \\
\hline $\begin{array}{l}\text { Peak expiratory flow rate } \\
\text { (PEFR) }\end{array}$ & Indirect measure \\
\hline $\begin{array}{l}\text { Airway } \\
\text { hyper-responsiveness }\left(\mathrm{PC}_{20}\right)\end{array}$ & Indirect measure \\
\hline $\begin{array}{l}\text { Fraction of exhaled nitric } \\
\text { oxide }\left(F_{E} N O\right)\end{array}$ & $\begin{array}{l}\text { Surrogate marker; validated, standardized, } \\
\text { clinically approved, immediate results }\end{array}$ \\
\hline Induced sputum & Semi-invasive \\
\hline Eosinophil counts & Direct measure, validated, standardized \\
\hline $\begin{array}{l}\text { Biomolecules in sputum } \\
\text { supernatants }\end{array}$ & $\begin{array}{l}\text { Biomarkers; not standardized, validation } \\
\text { required for immunoassays }\end{array}$ \\
\hline
\end{tabular}

$P C_{20}$ : "provocative dose" of an agent, like methacholine, causing a $20 \%$ fall in forced expiratory volume in $1 \mathrm{~s}\left(F E V_{1}\right)$.

Table 2 | Non-invasive monitoring of airway inflammation: innovative techniques.

\begin{tabular}{|c|c|}
\hline Technique & Characteristics \\
\hline $\begin{array}{l}\text { Exhaled breath } \\
\text { condensate (EBC) }\end{array}$ & Non-invasive, not standardized \\
\hline $\begin{array}{l}\text { Measurement of } \\
\text { biomolecules }\end{array}$ & $\begin{array}{l}\text { Biomarkers; some biomolecules measured } \\
\text { with reference analytical techniques, } \\
\text { validation required for most immunoassays }\end{array}$ \\
\hline $\begin{array}{l}\text { Metabolomics with } \\
\text { nuclear magnetic } \\
\text { resonance (NMR) } \\
\text { spectroscopy }\end{array}$ & $\begin{array}{l}\text { Biomarkers; highly specific, quantitative, } \\
\text { analysis of multidimensional data requiring } \\
\text { algorithms for pattern recognition }\end{array}$ \\
\hline Electronic nose (E-nose) & $\begin{array}{l}\text { Non-invasive, not standardized } \\
\text { Biomarkers; analysis of multidimensional data } \\
\text { requiring algorithms for pattern recognition }\end{array}$ \\
\hline Breath analysis with & Biomarkers; highly specific, quantitative \\
\hline
\end{tabular}

gas-chromatography/mass

spectrometry (GC/MS) 

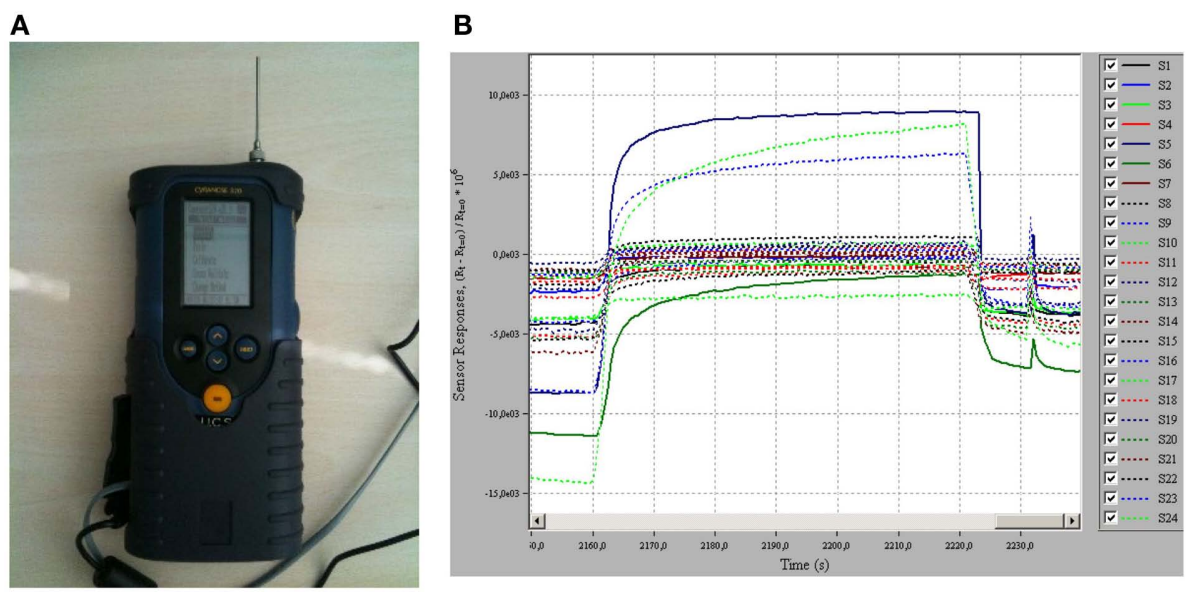

FIGURE 2 | Breath analysis with electronic nose. (A) An electronic nose (Cyranose 320, Smiths Detection, Pasadena, USA). (B) A typical response obtained when electronic nose sensor array is exposed to a breath sample.

$\mathrm{F}_{\mathrm{E}} \mathrm{NO}$ correlates with eosinophilic inflammation and AHR before corticosteroid treatment, is useful in asthma diagnosis, decreases rapidly after anti-inflammatory treatment and predicts response, increases during asthma exacerbations, and can be used to monitor compliance (Bates and Silkoff, 2003; Barnes et al., 2010). However, $\mathrm{F}_{\mathrm{E}} \mathrm{NO}$ only measures one component of the asthmatic inflammatory response which is a complex pathophysiological process and is affected by several factors including atopy and gene polymorphisms (Bates and Silkoff, 2003). Moreover, single breath $\mathrm{F}_{\mathrm{E}} \mathrm{NO}$ measurement is difficult in preschool children and the dose-response to ICS is steep and plateaus early (Bates and Silkoff, 2003). In a single-blind, placebo-controlled trial, in which 97 adults with asthma who had been regularly receiving treatment with ICS were randomly assigned to have their glucocorticoid dose adjusted on the basis of either $\mathrm{F}_{\mathrm{E}} \mathrm{NO}$ or based on conventional guidelines, maintenance doses of ICS were significantly reduced $\left(-270 \mu \mathrm{g}\right.$ of fluticasone per day, 95\% CI, 112-430) in the $\mathrm{F}_{\mathrm{E}} \mathrm{NO}$ group without compromising asthma control (Smith et al., 2005). A systematic review aiming at assessing the efficacy of tailoring asthma interventions based on $\mathrm{F}_{\mathrm{E}} \mathrm{NO}$ compared to conventional methods (symptoms and lung function tests) and including two adult (Smith et al., 2005; Shaw et al., 2007) and four pediatric studies (Pijnenburg et al., 2005; Fritsch et al., 2006; Szefler et al., 2008; de Jongste et al., 2009), reported no between-group difference for the primary outcome of asthma exacerbations or for other asthma-related outcomes (symptoms, lung function tests, $\mathrm{F}_{\mathrm{E}} \mathrm{NO}$; Petsky et al., 2009). Post hoc analysis showed significant reduction in mean daily dose ICS in adults with asthma in whom treatment was based on $\mathrm{F}_{\mathrm{E}} \mathrm{NO}$ in comparison to symptoms (mean difference $-450 \mu \mathrm{g} ; 95 \% \mathrm{CI}-677$ to $-223 \mu \mathrm{g}$ budesonide equivalent/day; Petsky et al., 2009). This trend was not observed in children or adolescents with asthma in whom there was a significant increase in ICS dose in the $\mathrm{F}_{\mathrm{E}} \mathrm{NO}$ strategy group (mean difference of $140 \mu \mathrm{g}$; 95\% CI 29 to $251 \mu \mathrm{g}$ budesonide equivalent/day; Petsky et al., 2009). However, the studies included in this meta-analysis differed as regard to definition of asthma exacerbations, $\mathrm{F}_{\mathrm{E}} \mathrm{NO}$ cut off concentrations, duration of study, and the way in which $\mathrm{F}_{\mathrm{E}} \mathrm{NO}$ was used to adjust therapy (Petsky et al., 2009). The role of $\mathrm{F}_{\mathrm{E}} \mathrm{NO}$ measurement to tailor the dose of ICS is not currently defined and requires further studies.

\section{SPUTUM EOSINOPHILS}

Sputum induction is a semi-invasive technique for assessing airway inflammation. Measurement of sputum eosinophil and other inflammatory cell counts is a direct, standardized, and validated method for assessing airway inflammation (Djukanovic et al., 2002; Efthimiadis et al., 2002; Paggiaro et al., 2002; Vignola et al., 2002). Assessment of sputum inflammatory cells can be used to identify asthma phenotypes and define those phenotypes which respond to pharmacological treatment (Bakakos et al., 2011). Elevated sputum eosinophilia $(>3 \%)$ is frequently observed in patients with asthma, although some patients have a predominant neutrophilic or combined phenotype (Wenzel, 2006; Gibson, 2009). Clinically useful applications of induced sputum analysis include assessment of adequacy of ICS therapy and compliance, long-term therapy management in asthma, oral corticosteroid dose adjustment in refractory asthma and assessment of occupational asthma (Green et al., 2002; Chlumský et al., 2006; Jayaram et al., 2006; Gibson, 2009). However, sputum induction is not generally well accepted to patients, can cause bronchoconstriction itself, requires processing of samples within $2 \mathrm{~h}$ and specialized staff (Efthimiadis et al., 2002), and can be unfeasible in children and patients with severe asthma. In a systematic review including 215 adults with asthma, assessment of sputum eosinophil counts for asthma control significantly reduced the number of patients who had asthma exacerbations compared with tailored interventions based on symptoms ( 52 versus $77 ; P=0.0006$ ), odds ratio (OR) 0.36 (95\% CI 0.20 to 0.64$)$. Number needed to treat (NNT) for benefit was 6 (95\% CI 4-32) over 52 weeks (Petsky et al., in press). Although the number of patients with asthma included in this systematic review is relatively limited and the studies considered have a degree of heterogeneity, these findings indicate that tailoring of treatment based on sputum eosinophils in adults with asthma is effective in reducing asthma exacerbations (Petsky et al., 
in press). Although unpractical to perform routinely, analysis of sputum eosinophils is a semi-invasive technique for assessing airway inflammation that can provide an additional tool to guide the management of patients with asthma (Bakakos et al., 2011).

\section{INFLAMMATORY BIOMARKERS IN SPUTUM SUPERNATANTS}

Several inflammatory biomarkers, including eosinophil-derived proteins, NO-derived metabolites, eicosanoids, cytokines, and airway remodeling-associated proteins can be measured in sputum supernatants in patients with asthma (Bakakos et al., 2011). However, measurement of biomolecules in sputum supernatants is often affected by interferences between reagents used for sputum processing (e.g., dithiothreitol) and immunoassays, which are generally used as analytical techniques. Immunoassays for measuring biomolecules in sputum supernatants require validation before this approach for assessing airway inflammation can be considered for clinical applications.

\section{INFLAMMATORY BIOMARKERS IN EXHALED BREATH CONDENSATE}

Analysis of EBC is a non-invasive method for studying the composition of airway lining fluid and has the potential for assessing respiratory inflammation (Montuschi, 2002). Several biomolecules including leukotrienes (LTs), 8-isoprostane, prostaglandins (PGs), hydrogen peroxide, $\mathrm{NO}$-derived products, and hydrogen ions, have been detected in healthy subjects (Montuschi, 2007). Some of these inflammatory mediators in EBC are elevated in patients with different respiratory diseases including asthma (Montuschi, 2007; Horváth et al., 2005). As it is completely non-invasive, analysis of EBC is suitable for longitudinal studies, is potentially useful for assessing the response to pharmacological treatment, and might also have a diagnostic value by identifying selective profiles of biomarkers of lung diseases (Montuschi, 2002, 2007). Biomolecules, including $\mathrm{LTB}_{4}$ (Montuschi et al., 2004), 8-isoprostane (Carpenter et al., 1998; Syslová et al., 2008), PGE 2 (Carpenter et al., 1998), and small molecular weight metabolites (de Laurentiis et al., 2008) have been measured in EBC using reference analytical techniques such as mass spectrometry or nuclear magnetic resonance spectroscopy. However, several methodological issues including standardization of procedures for EBC analysis and validation of some analytical techniques need to be addressed before EBC analysis can be considered in the clinical setting (Montuschi, 2007). Further research in this area is warranted due to the relative lack of non-invasive methods for assessing airway inflammation.

\section{ELECTRONIC NOSE}

Several volatile organic compounds (VOCs), including isoprene, 1,2-pentadiene, acetone, and ethane, have been identified in exhaled breath in healthy subjects by gas-chromatography/mass spectrometry (Phillips, 1997; Phillips et al., 1999). Identification of selective VOC patterns in exhaled breath is potentially useful as a biomarker of asthma. An electronic nose is an artificial sensor system that consists of an array of chemical sensors for VOC detection and an algorithm for pattern recognition (Röck et al., 2008; Figure 2). The electronic nose discriminates between patients with asthma and healthy subjects (Dragonieri et al., 2007; Montuschi et al., 2010) and between patients with asthma and chronic obstructive pulmonary disease (Fens et al., 2009). The electronic nose has been reported to have a high diagnostic performance that can be increased when combined with $\mathrm{F}_{\mathrm{E}} \mathrm{NO}$ (Montuschi et al., 2010). However, large studies are required to definitively establish the diagnostic performance of the electronic nose. Whether this approach based on electronic nose will translate into an early diagnosis of asthma and a novel non-invasive technique for asthma phenotyping and management has to be clarified.

\section{BIOMARKERS OF AIRWAY REMODELING}

Bronchoscopy with bronchial biopsies enables a direct assessment of airway remodeling, but this technique is invasive and not generally indicated in patients with asthma who can be at higher risk of bronchospasm due to AHR. Functional outcome measures including changes in pulmonary function and AHR over time co-varies with airway structural changes, but these measures are not direct and specific, not sufficiently sensitive, and the interactions are complex (Larsson, 2010). Several biomolecules which are pathophysiologically involved in airway structural changes that characterize asthma have been measured in different biological fluids, but no specific validated inflammatory biomarkers of airway remodeling obtained from sputum, bronchoalveolar lavage (BAL), blood, exhaled air, EBC, urine, or saliva are currently available (James and Wenzel, 2007). Identification of non-invasive specific, sensitive, and validated biomarkers of airway remodeling would provide important information on disease severity and progression in the individual patients with asthma and new relevant outcome measures for assessing the effect of pharmacological treatment with potential implications for the management of asthmatic patients.

Promising results have been reported with novel imaging techniques and recent studies have demonstrated how structural airway and lung changes can be detected on computerized tomography (Larsson, 2010).

\section{ASTHMA CONTROL AND AIRWAY REMODELING AIRWAY STRUCTURAL CHANGES IN ASTHMA}

In patients with asthma, chronic airway inflammation is associated with structural changes known as airway remodeling (James and Wenzel, 2007) which include epithelial damage with decreased adhesion of epithelial cells, known as epithelial fragility, reticular basement membrane thickening, subepithelial fibrosis with extracellular matrix deposition, hypertrophy and hyperplasia of smooth muscle cells, recruitment and activation of myofibroblasts, goblet cell hyperplasia, hypertrophy of submucosal mucous glands, angiogenesis, and likely direct transformation of epithelial cells into mesenchymal cells (Bai, 2010; Bergeron et al., 2010; Halwani et al., 2010). These structural changes contribute to thickening of airway walls and, consequently, lead to airway obstruction, AHR, edema, and mucus hypersecretion (Bergeron et al., 2010).

\section{AIRWAY REMODELING: PATHOPHYSIOLOGICAL IMPLICATIONS IN ASTHMA}

Airway remodeling contributes to asthma persistence, airflow obstruction, lung function decline, and clinical severity (Bai, 2010), does not resolve spontaneously (Royce and Tang, 2009), and is commonly attributed to an underlying chronic inflammatory process (Homer and Elias, 2000; Murray, 2008; Janson, 2010). 
However, relationships between airway inflammation and remodeling are not completely known. Airway remodeling is a key feature of the $5-10 \%$ of the asthmatic patients with severe disease (Girodet et al., 2011), but can also be present in patients with mild persistent asthma (Royce and Tang, 2009; Larsson, 2010). Some remodeling changes such as reticular basement membrane thickening (Saglani et al., 2007) and increase in airway smooth muscle mass (Regamey et al., 2008) can occur early in the course of asthma pathogenesis (Bush, 2008; Royce and Tang, 2009). Airway remodeling is partially reversible in mild persistent asthma but mostly irreversible in severe persistent asthma (Halwani et al., 2010). Early diagnosis and prevention of airway remodeling has the potential to decrease disease severity, improve control and prevent disease expression (Bergeron et al., 2010).

\section{ASSESSMENT OF DRUG EFFECTS ON ASTHMA AIRWAY REMODELING}

Assessment of the effects of ICS and other anti-inflammatory drugs on airway remodeling in patients with asthma is difficult due to the relative lack of prospective, randomized, double-blind, controlled, long-term studies aiming at assessing the effect of pharmacological treatment on clinical and physiological outcomes (Walters et al., 2007); the lack of non-invasive validated biomarkers for assessing airway remodeling that requires bronchoscopic and biopsy studies; the relative inadequacy of predictive experimental models for testing the anti-remodeling effects of drugs; the different effect of pharmacological treatment on different types of airway structural and inflammatory cells and mediators that can be involved in the airway remodeling process (Walters et al., 2007).

\section{EFFECTS OF ICS ON ASTHMA CONTROL, AIRWAY INFLAMMATION, AND AIRWAY REMODELING}

Regular treatment with ICS may partly have a beneficial effect on airway remodeling in asthma. In a 24-month randomized, prospective, parallel trial in patients with mild-to-moderate asthma, adjustment of ICS dose according to AHR in addition to existing guidelines (AHR strategy) was more effective than adjustment of ICS based on existing guidelines only (reference strategy) in controlling asthma, reducing chronic airway inflammation, and reducing airway remodeling as reflected by reticular basement membrane thickness (Sont et al., 1999). However, the greater efficacy observed in the AHR strategy group required higher ICS doses, the median difference in treatment with ICS being $\pm 400 \mu \mathrm{g}$ per day (Sont et al., 1999).

In a 12-month double-blind, randomized, placebo-controlled, parallel-group study in mild-to-moderate steroid-naive patients with asthma, inhaled fluticasone propionate at a dose of $750 \mu \mathrm{g}$ b.i.d. reduced BAL inflammatory cells and improved $\mathrm{FEV}_{1}$ after 3 months of treatment with no further improvement at 12 months (Ward et al., 2002). By contrast, reduction in reticular basement membrane thickness, a component of airway remodeling, was only observed at 12 months (Ward et al., 2002). There was a progressive reduction in AHR throughout the study with the larger effect associated with the later improvement in airway remodeling (Ward et al., 2002).

Taken together, this evidence suggests that airway inflammation, AHR, and airway remodeling are interrelated and improve with ICS (Ward et al., 2002, 2005). Effects of ICS treatment on different outcome measures do not occur at the same time, with prolonged treatment required for achieving maximal benefit in airway remodeling and AHR (Ward et al., 2002, 2005). Determining the appropriate dose of ICS only based on clinical and functional outcomes, as specified in current international guidelines, and even on direct inflammatory outcome measures may be over simplistic and support the view that regular treatment with ICS should be started early and be on long-term basis, even in patients with relatively mild asthma (Ward et al., 2002, 2005). However, measurement of reticular basement membrane thickness and even AHR for ICS dose-finding and guiding duration of treatment is not suitable for routine longitudinal assessment of patients with asthma. Moreover, reticular basement membrane thickness is one component, although relevant, of airway remodeling, a complex process, which is only partially responsive to ICS (Murray, 2008). For instance, treatment with oral corticosteroids for 2 weeks does not affect type I and type III collagen deposition, a typical feature of airway remodeling, or the expression of transforming growth factor- $\beta$, a profibrotic cytokine that stimulates fibroblasts to secrete extracellular matrix proteins including collagen I and III (Chakir et al., 2003). By contrast in another study, inhaled beclomethasone at a dose of $800 \mu \mathrm{g}$ daily for 6 months decreased type III collage deposition in patients with asthma (Hoshino et al., 1999).

Whether ICS have a predominant positive or negative effect on airway epithelial cells in patients with asthma is not completely defined (Walters et al., 2007). Treatment with ICS decreases BAL epithelial cell counts concomitant with amelioration of clinical outcomes, possibly reflecting normalization of asthma epithelial fragility (Walters et al., 2007). By contrast, the epidermal growth factor pathway that is up-regulated in epithelial cells in patients with asthma seems to be resistant to ICS treatment (Puddicombe et al., 2000; Polosa et al., 2002). In vitro studies show that fluticasone propionate, at therapeutic concentrations, is able to revert myofibroblasts to a normal phenotype (Cazes et al., 2001), but data on the effect of ICS on airway smooth muscle cells in vivo are not available (Murray, 2008).

To summarize, ICS have a beneficial effect on some, but not all, components involved in airway remodeling in asthma (Murray, 2008). In analogy to ICS therapeutic effects on diverse outcomes (clinical, functional, AHR, airway inflammation, airway remodeling) that occur at different times and have differing dose-response relationships (Walters et al., 2007), different aspects of airway remodeling might have different responses and timescales to ICS (Ward et al., 2002, 2005).

\section{NON-STEROIDAL DRUGS FOR AIRWAY REMODELING IN ASTHMA}

Data on the effectiveness of LTRA, phosphodiesterase inhibitors, mast cell tryptase inhibitors, and peroxisome proliferatoractivated receptor- $\gamma$ agonists in the treatment or prevention of airway remodeling are limited (Royce and Tang, 2009). In an animal model of human asthma, montelukast, a LTRA, prevents allergeninduced airway changes and reverses structural changes including airway smooth muscle cell layer thickening and subepithelial fibrosis, that are not affected by corticosteroid treatment (Henderson et al., 2006). In one biopsy study, montelukast (10 mg once daily for 8 weeks) reduced airway myofibroblast accumulation in 
patients with asthma following low-dose allergen challenge (Kelly et al., 2006). More studies are required to determine the clinical relevance of these findings with LTRA in preventing airway remodeling and/or reversing established airway structural changes in patients with asthma.

A better understanding of airway remodeling in asthma is likely to prompt the identification and development of new pharmacological therapies for asthma beyond control of symptoms, lung function, and inflammation (Royce and Tang, 2009). Modulation of the asthmatic airway remodeling will probably become an even more important endpoint in the near future (Sandström, 2010).

\section{PHARMACOLOGICAL STRATEGIES IN MILD PERSISTENT ASTHMA: CONTINUOUS OR ON-DEMAND TREATMENT CONTROLLED RANDOMIZED CLINICAL TRIALS}

Patients with mild asthma who do not perceive the need for daily therapy may be using their treatment intermittently. Three studies compared regular versus on-demand treatment for mild persistent asthma, the Improving Asthma Control Trial (IMPACT; Boushey et al., 2005), the Beclomethasone plus Salbutamol Treatment (BEST) study (Papi et al., 2007), and the Helsinki Early Intervention Childhood Asthma Study (Turpeinen et al., 2008).

In the IMPACT study, a 12-month, double-blind, doubledummy, parallel-group trial, 225 adults with long-standing mild persistent asthma were randomized to receive daily treatment with inhaled budesonide ( $200 \mu \mathrm{g}$ b.i.d.), oral zafirlukast ( $20 \mathrm{mg}$ b.i.d.), or placebo (Boushey et al., 2005). All patients were instructed in the use of intermittent short-course corticosteroid treatment based on a high-dose of inhaled budesonide ( $800 \mu \mathrm{g}$ b.i.d. for 10 days) or oral prednisone $(0.5 \mathrm{mg}$ per kilogram of body weight per day for 5 days) guided by a symptom-based action plan (Boushey et al., 2005). No significant between-group differences were found in change in two-week average morning PEF from randomization to the end of the trial, the primary outcome measure, quality of life, and asthma exacerbations (Boushey et al., 2005). However, greater improvements in pre-bronchodilator $\mathrm{FEV}_{1}, \mathrm{AHR}$, sputum eosinophils, $\mathrm{F}_{\mathrm{E}} \mathrm{NO}$, and symptom-free days were observed in the budesonide group (Boushey et al., 2005; Figure 3). This study indicates that treating mild persistent asthma with short, intermittent courses of inhaled or oral corticosteroids taken as symptoms worsen is possible (Boushey et al., 2005). However, it should be noted that continuous treatment with inhaled budesonide was superior to intermittent treatment with corticosteroids in improving outcome measures of airway inflammation. In particular, at the end of the study, the group of asthmatic patients that received regular treatment with ICS had reduced sputum eosinophil counts $(P<0.03)$, whereas those asthmatic patients who received intermittent treatment with corticosteroids had increased sputum eosinophil cell counts $(P<0.03)$ and no difference was observed in the zafirlukast group $(P=0.71)$. Between-group differences were highly significant $(P=0.007)$. A similar trend was observed with $\mathrm{F}_{\mathrm{E}} \mathrm{NO}$. These data not only demonstrate the different efficacy on airway inflammatory outcomes between the two pharmacological strategies (regular versus on-demand), but also indicate that airway inflammation increases if not regularly treated with ICS. Continuous treatment with inhaled budesonide also produced a significant improvement in AHR that was not observed with

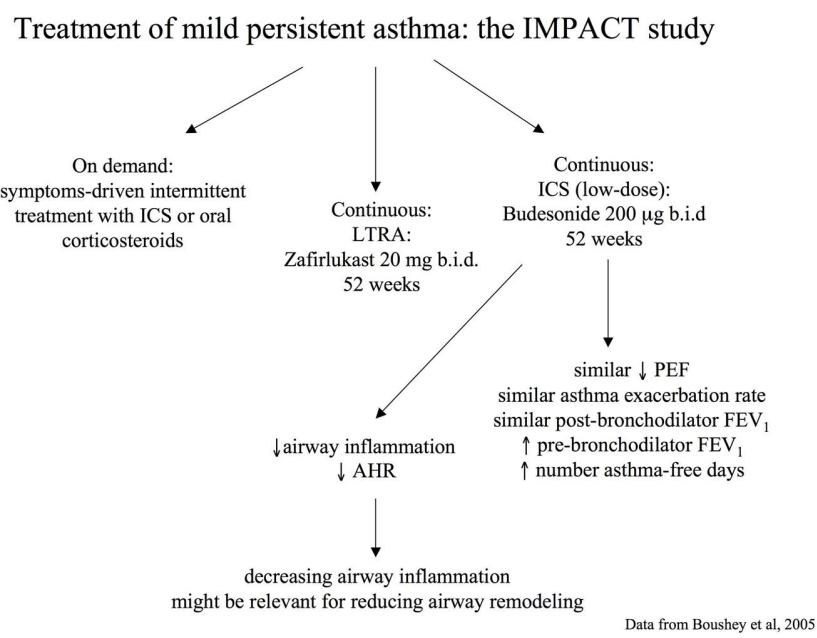

FIGURE 3 | Pharmacological strategies for treatment of persistent mild asthma: the Improving Asthma Control Trial (IMPACT; Boushey et al., 2005).

intermittent treatment with corticosteroids or continuous treatment with zafirlukast. These effects might have important implications in the management of patients with asthma as controlling airway inflammation and AHR might have a role in preventing and/or reducing the progression of airway remodeling and, consequently, worsening of symptoms and lung function (Canonica, 2006; Murray, 2008).

In the BEST study, a 6-month, double-blind, double-dummy, randomized, parallel-group trial, 455 patients with mild persistent asthma were randomly assigned to receive one of the four inhaled treatments: placebo twice daily plus on-demand combination therapy $(250 \mu \mathrm{g}$ of beclomethasone and $100 \mu \mathrm{g}$ of salbutamol in a single inhaler); placebo twice daily plus on-demand therapy (100 $\mu \mathrm{g}$ of salbutamol); regular beclomethasone therapy $(250 \mu \mathrm{g}$ twice daily) plus salbutamol ( $100 \mu \mathrm{g})$ on-demand; or regular combination therapy $(250 \mu \mathrm{g}$ of beclomethasone and $100 \mu \mathrm{g}$ of salbutamol in a single inhaler) twice daily plus salbutamol on-demand (Papi et al., 2007). The morning PEF during the last 2 weeks of the 6-month treatment period, which was the primary outcome, was significantly higher and the number of exacerbations during the 6-month treatment was significantly lower in the on-demand combination therapy group than in the on-demand salbutamol therapy group, but the values in the on-demand combination therapy group were not significantly different from those in the groups receiving regular beclomethasone therapy or regular combination therapy (Papi et al., 2007). These data would suggest that the symptom-driven use of a combination of inhaled beclomethasone and salbutamol would be as effective as regular use of inhaled beclomethasone twice daily in patients with mild persistent asthma (Papi et al., 2007). However, no biomarker of airway inflammation was measured in this study. For this reason, it is not known whether these pharmacological strategies are equivalent for controlling airway inflammation. Moreover, the non-inferiority level for the primary outcome was set at $10 \%$, a value which is rather high for non-inferiority studies. The maximum difference considered 
to indicate between-group clinical equivalence corresponded to $40 \mathrm{~L} / \mathrm{min}$ ( $10 \%$ of the expected mean PEF of $400 \mathrm{~L} / \mathrm{min}$ at the end of the study; Papi et al., 2007). Although this limit was selected on the basis of guidelines suggesting that therapy should not be changed if PEF varies by less than 20\% (NAEPP National Asthma Education and Prevention Program: Expert Panel Report II, 1997), it is not known whether such a difference in mean PEF has clinical consequences.

In the Helsinki Early Intervention Childhood Asthma Study, a 18-month controlled, randomized, double-blind, parallel-group, intervention trial, 176 children aged 5-10 years with newly diagnosed asthma were randomly assigned to three treatment groups: (1) regular treatment with budesonide (100-400 $\mu \mathrm{g}$ twice daily) for months 1-18; (2) regular treatment with budesonide for months 1-6, then budesonide for exacerbations as-needed for months 7-18; or (3) disodium cromoglycate (10 mg t.d.s.) for months 1-18 (Turpeinen et al., 2008). Compared with disodium cromoglycate the initial regular budesonide treatment resulted in a significantly improved lung function, fewer asthma exacerbations and a small but significant decline in growth velocity. During months $7-18$, children with asthma who were being receiving continuous treatment with budesonide had significantly fewer asthma exacerbations compared to those in the other groups (Turpeinen et al., 2008). No significant between-group differences were observed in the morning PEF, the primary efficacy variable (Turpeinen et al., 2008). The results of this study show that continuous treatment with budesonide is more effective in controlling asthma exacerbation but less tolerated than a therapeutic strategy based on intermittent use of budesonide given on-demand (Turpeinen et al., 2008). In analogy to the BEST study, the effects of the different pharmacological strategies on outcomes reflecting airway inflammation (e.g., $\mathrm{F}_{\mathrm{E}} \mathrm{NO}$ and sputum eosinophil cell counts) were not assessed.

\section{ADVANTAGES AND DISADVANTAGES}

The studies discussed above are not directly comparable due to differences in study population, study design, and medications used. The conclusions are not univocal and support the concept that different therapeutic strategies with apparently similar efficacy, but likely different safety, can be used in the treatment of mild persistent asthma. On-demand treatment is certainly more accepted by patients with mild persistent asthma who have infrequent symptoms as this strategy helps in overcoming a possible poor compliance and a common "steroid-phobia" observed with a regular treatment. Considerations on the economic burden and side effects of a chronic controller therapy can further contribute to favor a self-management plan of symptom-driven treatment, especially in young patients who may require life-long treatment with ICS. However, even if on-demand treatment seems to have a similar, but not completely equivalent, efficacy on clinical and functional outcomes, it does not suppress chronic airway inflammation or the AHR associated with asthma, as shown in the IMPACT study (Boushey et al., 2005). Thus, there is the possibility that patients without a regular treatment with ICS may develop a more severe asthma accompanied by airway remodeling (Janson, 2010) and a progressive loss of lung function (Fabbri, 2005). However, the possible clinical and functional consequences of persistent, not controlled, airway inflammation in patients with asthma have to be established (Lazarus, 2006). Moreover, it has also be noticed that current asthma therapies, including ICS, are successful in treating airway inflammation, but do not specifically target the remodeling process, so that airway structural changes progress despite optimal control of inflammation, and airway remodeling is not eradicated or prevented despite widespread use of anti-inflammatory treatments (Royce and Tang, 2009). More generally, the relationships between asthma symptoms, lung function, AHR, airway inflammation and remodeling, the impact of airway inflammation and remodeling on asthma severity and progression, and the effects of pharmacological treatment on these outcomes and the natural history of asthma require further research. Persistent airway inflammation has been described in patients with complete clinical remission of asthma (van den Toorn et al., 2001). The clinical implications of this finding have to be clarified.

\section{CHOOSING THE OUTCOME MEASURES}

The choice of the outcome measures that have to be included in clinical trials evaluating different therapeutic strategies for asthma is important. Morning PEF, which was the primary outcome measure in both IMPACT and BEST studies, could not be a sufficiently sensitive efficacy parameter for assessing asthma control in adults, as already shown in children (Anonymous, 2000; Turpeinen et al., 2008). The assessment of asthma control should incorporate not only outcomes reflecting current clinical control, such as symptoms, reliever use and lung function, and future risk, such as exacerbations and lung function decline (Taylor et al., 2008), but also reflecting airway inflammation. Drugs for asthma control, which are principally anti-inflammatory, are not currently assessed on the basis of their effects on inflammatory parameters. The reasons for that are related to the relative lack of validated noninvasive biomarkers of airway inflammation, but also involves a skeptical attitude about their biological relevance supported by recent meta-analyses based on heterogeneous, relatively limited data (Petsky et al., 2009, in press). Part of this skepticism rely upon the overwhelming number of potential non-invasive biomarkers of airway inflammation that have been proposed, with evidence for clinical utility for only two of them, $\mathrm{F}_{\mathrm{E}} \mathrm{NO}$ and sputum eosinophil counts. More validated biomarkers of inflammation are warranted. On the other hand, drugs for asthma control are not currently assessed on the basis of their primary effect, which is anti-inflammatory, but on clinical and functional outcomes. Assessing drugs for asthma control based on direct outcome measures of airway inflammation would likely lead to a more rational pharmacological intervention.

\section{EFFECTS ON NATURAL HISTORY OF ASTHMA}

Continuous treatment with ICS, alone or in combination with other anti-asthmatic drugs, achieves and maintains asthma control, although there is no agreement that this pharmacological strategy prevents progressive decline in lung function over time (Anonymous, 2000; Pauwels et al., 2003). Both the IMPACT and BEST studies are likely too short to formally address this issue and longer controlled randomized clinical trials are required to properly assess whether airway inflammation must be suppressed over time to prevent the progression of asthma. 
Treatment with ICS likely decreases the rate of $\mathrm{FEV}_{1}$ decline, although this is currently difficult to establish due to the lack of randomized double-blind controlled studies that show such an effect (Janson, 2010). Early treatment with ICS can result in long-lasting control of patients with mild asthma (Haahtela et al., 1994; Selroos et al., 1995). Maintenance therapy generally requires a reduced dose, but discontinuation of treatment is often accompanied by asthma exacerbation (Haahtela et al., 1994). In both adults (Haahtela et al., 1994; Selroos et al., 1995) and children (Agertoft and Pedersen, 1994) with asthma, ICS effect was negatively correlated with duration of disease as patients with shorter duration of asthma symptoms had a greater improvement in lung function. Two studies in infants and children with wheezing and risk factors for developing asthma indicate that ICS do not alter the natural history of the disease (Bisgaard et al., 2006; Guilbert et al., 2006). However, asthma has long-term effects on lung function as indicated by the Copenhagen City Heart Study that showed greater decline rates in $\mathrm{FEV}_{1}$ over time in patients with asthma compared with those observed in non-asthmatic subjects (Lange et al., 1998). These asthma-related effects on lung function could be due to persistent, uncontrolled, airway inflammation (Murray, 2008; Janson, 2010).

\section{A PERSONALIZED THERAPEUTIC APPROACH}

Whether all patients with mild persistent asthma should receive daily long-term treatment with ICS or an alternative antiinflammatory drug is debated. It is likely that asthma, even within the same severity class, is a more heterogeneous disease than was previously recognized and that current treatment guidelines need a fine-tuning change (Lazarus, 2006). Patients with mild asthma

\section{REFERENCES}

Agertoft, L., and Pedersen, S. (1994). Effects of long-term treatment with an inhaled corticosteroid on growth and pulmonary function in asthmatic children. Respir. Med. 88, 373-381.

Agertoft, L., and Pedersen, S. (2000). Effect of long-term treatment with inhaled budesonide on adult height in children with asthma. N. Engl. J. Med. 343, 1064-1069.

Anonymous. (2000). Long-term effects of budesonide or nedocromil in children with asthma. The Childhood Asthma Management Program Research Group. N. Engl. J. Med.343, 1054-1063.

Bai, T. R. (2010). Evidence for airway remodeling in chronic asthma. Curr. Opin. Allergy Clin. Immunol. 10, 82-86.

Bain, G., King, C. D., Rewolinski, M., Schaab, K., Santini, A. M., Shapiro, D., Moran, M., van de Wetering de Rooij, S., Roffel, A. F., Schuilenga-Hut, P., Milne, G. L., Lorrain, D. S., Li, Y., Arreda, J. M., Hutchinson, J. H., Prasit, P., and Evans, J. F. (2010). Pharmacodynamics and pharmacokinetics

who have their disease well controlled by regular treatment with ICS might be treated with only on-demand treatment plan as an intermediate step toward the suspension of controller medication (Fabbri, 2005). These patients require a strict monitoring to establish the efficacy of the on-demand treatment in controlling asthma. They likely represent only a select subgroup of patients with mild asthma in whom the on-demand treatment might be successfully adopted.

\section{CONCLUSIONS}

Until the relationship between symptoms, lung function tests, AHR, inflammatory biomarkers, and longer-term variables such as asthma exacerbations and airway remodeling is better understood, the regular treatment seems to be generally more appropriate than on-demand therapy to warrant a greater control of asthma.

Classification of asthma based on disease severity as recommended by national and international guidelines remains a cornerstone in the management of patients with asthma and data obtained from randomized clinical trials remain the best way for assessing drug efficacy and safety. However, the increasing evidence for heterogeneity of asthma, the growing emphasis on asthma subphenotypes, including molecular phenotypes identified by omics technologies, and their possible implications in terms of different asthma severity and progression and therapeutic response, are changing the paradigm of treating patients with asthma only based on classification of their disease severity to a pharmacological strategy more focused on the individual asthmatic patient. Following a common trend in medicine, pharmacological treatment of asthma is going toward a personalized approach.

asthma: from benchside to clinical practice. Can. Respir. J. 17, e85-e93.

Bibby, S., Healy, B., Steele, R., Kumareswaran, K., Nelson, H., and Beasley, R. (2010). Association between leukotriene receptor antagonist therapy and ChurgStrauss syndrome: an analysis of the FDA AERS database. Thorax 65, 132-138.

Bisgaard, H., Hermansen, M. N., Loland, L., Halkjaer, L. B., and Buchvald, F. (2006). Intermittent inhaled corticosteroids in infants with episodic wheezing. N. Engl. J. Med. 354, 1998-2005.

Bjermer, L., Bisgaard, H., Bousquet, J., Fabbri, L. M., Greening, A. P., Haahtela, T., Holgate, S. T., Picado, C., Menten, J., Dass, S. B., Leff, J. A., and Polos, P. G. (2003). Montelukast and fluticasone compared with salmeterol and fluticasone in protecting against asthma exacerbation in adults: one year, double blind, randomised, comparative trial. BMJ $327,891$.

Boushey, H. A., Sorkness, C. A., King, T. S., Sullivan, S. D., Fahy, J. V., Lazarus, S. C., Chinchilli, V.
M., Craig, T. J., Dimango, E. A., Deykin, A., Fagan, J. K., Fish, J. E., Ford, J. G., Kraft, M., Lemanske, R. F. Jr., Leone, F. T., Martin, R. J., Mauger, E. A., Pesola, G. R., Peters, S. P., Rollings, N. J., Szefler, S. J., Wechsler, M. E., Israel, E., and National Heart, Lung, and Blood Institute's Asthma Clinical Research Network. (2005). Daily versus asneeded corticosteroids for mild persistent asthma. N. Engl. J. Med. 352, 1519-1528.

Bush, A. (2008). How early do airway inflammation and remodeling occur? Allergol. Int. 57, 11-19.

Busse, W., and Kraft, M. (2005). Cysteinyl leukotrienes in allergic inflammation: strategic target for therapy. Chest 127, 1312-1326.

Busse, W., Raphael, G. D., Galant, S., Kalberg, C., Goode-Sellers, S., Srebro, S., Edwards, L., Rickard, K., and Fluticasone Proprionate Clinical Research Study Group. (2001). Low-dose fluticasone propionate compared with montelukast for first-line treatment of persistent asthma: a randomized clinical trial. J. Allergy Clin. Immunol. 107, 461-468. 
Canonica, G. W. (2006). Treating asthma as an inflammatory disease. Chest 130(Suppl. 1), 21S-28S.

Carpenter, C. T., Price, P. V., and Christman, B. W. (1998). Exhaled breath condensate isoprostanes are elevated in patients with acute lung injury or ARDS. Chest 114, 1653-1659.

Castro-Rodriguez, J. A., and Rodrigo, G. J. (2009). Efficacy of inhaled corticosteroids in infants and preschoolers with recurrent wheezing and asthma: a systematic review with meta-analysis. Pediatrics 123, e519-e525.

Cazes, E., Giron-Michel, J., Baouz, S., Doucet, C., Cagnoni, F., Oddera, S., Körner, M., Dasic, G., Testi, R., Azzarone, B., and Canonica, G. W. (2001). Novel anti-inflammatory effects of the inhaled corticosteroid fluticasone propionate during lung myofibroblastic differentiation. J. Immunol. 167, 5329-5337.

Chakir, J., Shannon, J., Molet, S., Fukakusa, M., Elias, J., Laviolette, M., Boulet, L. P., and Hamid, Q. (2003). Airway remodelingassociated mediators in moderate to severe asthma: effect of steroids on TGF-beta, IL-11, IL-17, and type I and type III collagen expression. J. Allergy Clin. Immunol. 111, 1293-1298.

Chlumský, J., Striz, I., Terl, M., and Vondracek, J. (2006). Strategy aimed at reduction of sputum eosinophils decreases exacerbation rate in patients with asthma. J. Int. Med. Res. 34, 129-139.

Colice, G. L. (2006). New developments in inhaled corticosteroids. Allergy Asthma Proc. 27, 332-340.

Dahlen, B., Nizankowska, E., Szczeklik, A., Zetterström, O., Bochenek, G., Kumlin, M., Mastalerz, L., Pinis, G., Swanson, L. J., Boodhoo, T. I., Wright, S., Dubé, L. M., and Dahlén, S. E. (1998). Benefits from adding the 5-lipoxygenase inhibitor zileuton to conventional therapy in aspirin-intolerant asthmatics. Am. J. Respir. Crit. Care Med. 157, 1187-1194.

Dahlen, S. E. (2006). Treatment of asthma with antileukotrienes: first line or last resort therapy? Eur. J. Pharmacol. 533, 40-56.

Dahlen, S. E., Malmström, K., Nizankowska, E., Dahlén, B., Kuna, P., Kowalski, M., Lumry, W. R., Picado, C., Stevenson, D. D., Bousquet, J., Pauwels, R., Holgate, S. T., Shahane, A., Zhang, J., Reiss, T. F., and Szczeklik, A. (2002). Improvement of aspirin-intolerant asthma by montelukast, a leukotriene antagonist: a randomized, doubleblind, placebo-controlled trial.
Am. J. Respir. Crit. Care Med. 165, 9-14.

de Jongste, J. C., Carraro, S., Hop, W. C., CHARISM Study Group, and Baraldi, E. (2009). Daily telemonitoring of exhaled nitric oxide and symptoms in the treatment of childhood asthma. Am. J. Respir. Crit. Care Med. 179, 93-97.

de Laurentiis, G., Paris, D., Melck, D., Maniscalco, M., Marsico, S. Corso, G., Motta, A., and Sofia, M. (2008). Metabonomic analysis of exhaled breath condensate in adults by nuclear magnetic resonance spectroscopy. Eur. Respir. J.32, 1175-1183.

Derendorf, H., Nave, R., Drollmann, A. Ceratoli, F., and Wurst, W. (2006). Relevance of pharmacokinetics and pharmacodynamics of inhaled corticosteroids to asthma. Eur. Respir. J. 28, 1042-1050.

Djukanovic, R., Sterk, P. J., Fahy, J. V., and Hargreave, F. E. (2002). Standardised methodology of sputum induction and processing. Eur. Respir. J. Suppl. 37, 1s-2s.

Donahue, J. G., Weiss, S. T., Livingston, J. M., Goetsch, M. A., Greineder, D. K., and Platt, R. (1997). Inhaled steroids and the risk of hospitalization for asthma. JAMA 277, 887-891.

Dragonieri, S., Schot, R., Mertens, B. J., Le Cessie, S., Gauw, S. A., Spanevello, A., Resta, O., Willard, N. P., Vink, T. J., Rabe, K. F., Bel, E. H., and Sterk, P. J. (2007). An electronic nose in the discrimination of patients with asthma and controls. J. Allergy Clin. Immunol. 120, 856-862.

Ducharme, F. M., Lasserson, T. J., and Cates, C. J. (2006). Long-acting $\beta$ agonists versus anti-leukotrienes as add-on therapy to inhaled corticosteroids for chronic asthma. Cochrane Database Syst. Rev. 4, CD003137.

Efthimiadis, A., Spanevello, A., Hamid, Q., Kelly, M. M., Linden, M., Louis, R., Pizzichini, M. M., Pizzichini, E., Ronchi, C., Van Overvel, F., and Djukanovic, R. (2002). Methods of sputum processing for cell counts, immunocytochemistry and in situ hybridisation. Eur. Respir. J. Suppl. 37, 19s-23s.

Evans, D. J., Taylor, D. A., Zetterstrom, O., Chung, K. F., O'Connor, B. J., and Barnes, P. J. (1997). A comparison of low-dose inhaled budesonide plus theophylline and highdose inhaled budesonide for moderate asthma. N. Engl. J. Med. 337, 1412-1418.

Fabbri, L. M. (2005). Does mild persistent asthma require regular treatment? N. Engl. J. Med. 352, 1589-1591.
Fens, N., Zwinderman, A. H., van der Schee, M. P., de Nijs, S. B. Dijkers, E., Roldaan, A. C., Cheung, D., Bel, E. H., and Sterk, P. J. (2009). Exhaled breath profiling enables discrimination of chronic obstructive pulmonary disease and asthma. Am. J. Respir. Crit. Care Med. 180, 1076-1082.

FitzGerald, J. M., and Shahidi, N. (2010). Achieving asthma control in patients with moderate disease. $J$. Allergy Clin. Immunol. 125, 307-311.

Fritsch, M., Uxa, S., Horak, F. Jr., Putschoegl, B., Dehlink, E., Szepfalusi, Z., and Frischer, T. (2006). Exhaled nitric oxide in the management of childhood asthma: a prospective 6-months study. Pediatr. Pulmonol. 41, 855-862.

Gibson, P. G. (2009). Inflammatory phenotypes in adult asthma: clinical applications. Clin. Respir. J. 3 , 198-206.

GINA Global Initiative for Asthma. (2010). Global Strategy for Asthma Management and Prevention. Available at: www.ginasthma.com

Girodet, P. O., Ozier, A., Bara, I., Tunon de Lara, J. M., Marthan, R., and Berger, P. (2011). Airway remodeling in asthma: new mechanisms and potential for pharmacological intervention. Pharmacol. Ther. 130, 325-337.

Green, R. H., Brightling, C. E., McKenna, S., Hargadon, B., Parker, D., Bradding, P., Wardlaw, A. J., and Pavord, I. D. (2002). Asthma exacerbations and sputum eosinophil counts: a randomised controlled trial. Lancet 360, 1715-1721.

Grzelewski, T., and Stelmach, I. (2009). Exercise-induced bronchoconstriction in asthmatic children: a comparative systematic review of the available treatment options. Drugs 69, 1533-1553.

Guilbert, T. W., Morgan, W. J., Geiger, R. S., Mauger, D. T., Boehmer, S. J., Szefler, S. J., Bacharier, L. B., Lemanske, R. F. Jr., Strunk, R. C., Allen, D. B., Bloomberg, G. R., Heldt, G., Krawiec, M., Larsen, G., Liu, A. H., Chinchilli, V. M., Sorkness, C. A., Taussig, L. M., and Martinez, F. D. (2006). Long-term inhaled corticosteroids in preschool children at high risk for asthma. N. Engl. J. Med. 354 1985-1997.

Gupta, R. S., and Weiss, K. B. (2009). The 2007 National Asthma Education and Prevention Program asthma guidelines: accelerating their implementation and facilitating their impact on children with asthma. Pediatrics 123(Suppl. 3), S193-S198.

Haahtela, T., Järvinen, M., Kava, T., Kiviranta, K., Koskinen, S., Lehtonen, K.,
Nikander, K., Persson, T., Selroos, O., Sovijärvi, A., Stenius-Aarniala, B., Svahn, T., Tammivaara, R., and Laitinen, L. A. (1994). Effects of reducing or discontinuing inhaled budesonide in patients with mild asthma. N. Engl. J. Med. 331, 700-705.

Halwani, R., Al-Muhsen, S., and Hamid, Q. (2010). Airway remodeling in asthma. Curr. Opin. Pharmacol. 10, 236-245.

Henderson, W. R. Jr., Chiang, G. K., Tien, Y. T., and Chi, E. Y. (2006) Reversal of allergen-induced airway remodeling by $\mathrm{CysLT}_{1}$ receptor blockade. Am. J. Respir. Crit. Care Med. 173, 718-728.

Homer, R. J., and Elias, J. A. (2000). Consequences of long-term inflammation. Airway remodeling. Clin. Chest Med. 21, 331-343.

Horváth, I., Hunt, J., Barnes, P. J, Alving, K., Antczak, A., Baraldi, E., Becher, G., van Beurden, W. J., Corradi, M., Dekhuijzen, R., Dweik, R. A., Dwyer, T., Effros, R., Erzurum, S., Gaston, B., Gessner, C., Greening, A., Ho, L. P., Hohlfeld, J., Jöbsis, Q., Laskowski, D., Loukides, S., Marlin, D., Montuschi, P., Olin, A. C., Redington, A. E., Reinhold, P., van Rensen, E. L., Rubinstein, I., Silkoff, P., Toren, K., Vass, G., Vogelberg, C., Wirtz, H., and ATS/ERS Task Force on Exhaled Breath Condensate. (2005). Exhaled breath condensate: methodological recommendations and unresolved questions. Eur. Respir. J. 26, 523-548.

Hoshino, M., Takahashi, M., Takai, Y., and Sim, J. (1999). Inhaled corticosteroids decrease subepithelial collagen deposition by modulation of the balance between matrix metalloproteinase- 9 and tissue inhibitor of metalloproteinase-1 expression in asthma. J. Allergy Clin. Immunol. 104, 356-363.

Irwin, R. S., and Richardson, N. D. (2006). Side effects with inhaled corticosteroids: the physician's perception. Chest 130(Suppl. 1), 41S-53S.

James, A. L., and Wenzel, S. (2007). Clinical relevance of airway remodelling in airway diseases. Eur. Respir. J. 30, 134-155.

Janson, C. (2010). The importance of airway remodelling in the natural course of asthma. Clin. Respir. J. 4(Suppl. 1), 28-34.

Jayaram, L., Pizzichini, M. M., Cook, R. J., Boulet, L. P., Lemière, C., Pizzichini, E., Cartier, A., Hussack, P., Goldsmith, C. H., Laviolette, M., Parameswaran, K., and Hargreave, F. E. (2006). Determining asthma treatment by monitoring sputum cell counts: effect on exacerbations. Eur. Respir. J. 27, 483-494. 
Kandane-Rathnayake, R. K., Matheson, M. C., Simpson, J. A., Tang, M. L., Johns, D. P., Mészáros, D., WoodBaker, R., Feather, I., Morrison, S., Jenkins, M. A., Giles, G. G., Hopper, J., Abramson, M. J., Dharmage, S. C., and Walters, E. H. (2009). Adherence to asthma management guidelines by middle-aged adults with current asthma. Thorax 64, 1025-1031.

Kelly, M. M., Chakir, J., Vethanayagam, D., Boulet, L. P., Laviolette, M. Gauldie, J., and O'Byrne, P. M. (2006). Montelukast treatment attenuates the increase in myofibroblasts following low-dose allergen challenge. Chest 130, 741-753.

Khalili, B., Boggs, P. B., and Bahna, S. L. (2007). Reliability of a new handheld device for the measurement of exhaled nitric oxide. Allergy 62, 1171-1174.

Kharitonov, S. A., Donnelly, L. E., Montuschi, P., Corradi, M., Collins, J. V., and Barnes, P. J. (2002). Dosedependent onset and cessation of action of inhaled budesonide on exhaled nitric oxide and symptoms in mild asthma. Thorax 57, 889-896.

Lange, P., Parner, J., Vestbo, J., Schnohr, P., and Jensen, G. (1998). A 15-year follow-up study of ventilatory function in adults with asthma. N. Engl. J. Med. 339, 1194-1200.

Larsson, K. (2010). Monitoring airway remodeling in asthma. Clin. Respir. J. 4(Suppl. 1), 35-40.

Lazarus, S. C. (2006). Mild persistent asthma: is any treatment needed? J. Allergy Clin. Immunol. 118, 805-808.

Lazarus, S. C., Chinchilli, V. M., Rollings, N. J., Boushey, H. A., Cherniack, R., Craig, T. J., Deykin, A., DiMango, E., Fish, J. E., Ford, J. G., Israel, E., Kiley, J., Kraft, M., Lemanske, R. F. Jr., Leone, F. T., Martin, R. J., Pesola, G. R., Peters, S. P., Sorkness, C. A., Szefler, S. J., Wechsler, M. E., Fahy, J. V., and National Heart Lung and Blood Institute's Asthma Clinical Research Network. (2007). Smoking affects response to inhaled corticosteroids or leukotriene receptor antagonists in asthma. Am. J. Respir. Crit. Care Med. 175, 783-790.

Leff, J. A., Busse, W. W., Pearlman, D., Bronsky, E. A., Kemp, J., Hendeles, L., Dockhorn, R., Kundu, S., Zhang, J., Seidenberg, B. C., and Reiss, T. F. (1998). Montelukast, a leukotriene-receptor antagonist, for the treatment of mild asthma and exercise-induced bronchoconstriction. N. Engl. J. Med. 339, 147-152.
Leigh, R., Vethanayagam, D., Yoshida, M., Watson, R. M., Rerecich, T., Inman, M. D., and O'Byrne, P. M. (2002). Effects of montelukast and budesonide on airway responses and airway inflammation in asthma. Am. J. Respir. Crit. Care Med. 166, 1212-1217.

Lemanske, R. F. Jr., Mauger, D. T., Sorkness, C. A., Jackson, D. J., Boehmer, S. J., Martinez, F. D., Strunk, R. C., Szefler, S. J., Zeiger, R. S., Bacharier, L. B., Covar, R. A., Guilbert, T. W., Larsen, G., Morgan, W. J., Moss, M. H., Spahn, J. D., and Taussig, L. M. (2010). Step-up therapy for children with uncontrolled asthma receiving inhaled corticosteroids. N. Engl. J. Med. 362, 975-985.

Lemanske, R. F. Jr., Sorkness, C. A., Mauger, E. A., Lazarus, S. C., Boushey, H. A., Fahy, J. V., Drazen, J. M., Chinchilli, V. M., Craig, T., Fish, J. E., Ford, J. G., Israel, E., Kraft, M., Martin, R. J., Nachman, S. A. Peters, S. P., Spahn, J. D., Szefler, S. J., and Asthma Clinical Research Network for the National Heart, Lung, and Blood Institute. (2001). Inhaled corticosteroid reduction and elimination in patients with persistent asthma receiving salmeterol: a randomized controlled trial. JAMA 285, 2594-2603.

Lofdahl, C. G., Reiss, T. F., Leff, J. A., Israel, E., Noonan, M. J., Finn, A. F., Seidenberg, B. C., Capizzi, T., Kundu, S., and Godard, P. (1999). Randomised, placebo controlled trial of effect of a leukotriene receptor antagonist, montelukast, on tapering inhaled corticosteroids in asthmatic patients. BMJ 319, 87-90.

Lorrain, D. S., Bain, G., Correa, L. D. Chapman, C., Broadhead, A. R., Santini, A. M., Prodanovich, P., Darlington, J. V., Hutchinson, J. H., King, C., Lee, C., Bacchi, C., Li, Y., Arreda, J. M., and Evans, J. F. (2009). Pharmacological characterization of 3-[3-tert-butylsulfanyl-1-[4-(6methoxy-pyridin-3-yl)-benzyl]5-(pyridin-2-ylmethoxy)-1Hindol-2-yl]-2,2-dimethyl-propionic acid (AM103), a novel selective 5-lipoxygenase-activating protein inhibitor that reduces acute and chronic inflammation. J. Pharmacol. Exp. Ther. 331, 1042-1050.

Lougheed, M. D., Lemière, C., Dell, S. D., Ducharme, F. M., Fitzgerald, J. M., Leigh, R., Licskai, C., Rowe, B. H., Bowie, D., Becker, A., and Boulet, L. P. (2010). Canadian Thoracic Society Asthma Management Continuum - 2010 Consensus Summary for children six years of age and over, and adults. Can. Respir. J. 17, 15-24.
Malmstrom, K., Rodriguez-Gomezm, G., Guerra, J., Villaran, C., Piñeiro, A., Wei, L. X., Seidenberg, B. C. and Reiss, T. F. (1999). Oral montelukast, inhaled beclomethasone, and placebo for chronic asthma. Ann. Intern. Med. 130, 487-495.

Melo, R. E., Solé, D., and Naspitz, C. K. (2003). Exercise-induced bronchoconstriction in children: montelukast attenuates the immediatephase and late-phase responses. J. Allergy Clin. Immunol. 111, 301-307.

Menzies, D., Nair, A., and Lipworth, B. J. (2007). Portable exhaled nitric oxide measurement: comparison with the "gold standard" technique. Chest $131,410-414$

Montuschi, P. (2002). Indirect monitoring of lung inflammation. Nat. Rev Drug Discov. 1, 238-242.

Montuschi, P. (2007). Analysis of exhaled breath condensate in respiratory medicine: methodological aspects and potential clinical applications. Ther. Adv. Respir. Dis. 1, 5-23.

Montuschi, P., and Peters-Golden, M. (2010). Leukotriene modifiers for asthma treatment. Clin. Exp. Allergy 40, 1732-1741.

Montuschi, P., Martello, S., Felli, M. Mondino, C., and Chiarotti, M. (2004). Ion trap liquid chromatography/tandem mass spectrometry analysis of leukotriene $B_{4}$ in exhaled breath condensate. Rapid Commun. Mass Spectrom. 18, 2723-2729.

Montuschi, P., Sala, A., Dahlén, S. E., and Folco, G. (2007). Pharmacological modulation of the leukotriene pathway in allergic airway disease. Drug Discov. Today 12, 404-412.

Montuschi, P., Santonico, M., Mondino, C., Pennazza, G., Mantini, G., Martinelli, E., Capuano, R., Ciabattoni, G., Di Natale, C., Barnes, P. J., and D'Amico, A. (2010). Diagnostic performance of an electronic nose, fractional exhaled nitric oxide and lung function testing in asthma. Chest $137,790-796$

Murray, C. S. (2008). Can inhaled corticosteroids influence the natural history of asthma? Curr. Opin. Allergy Clin. Immunol. 8, 77-81.

NAEPP National Asthma Education and Prevention Program: Expert Panel Report II. (1997). Guidelines for the Diagnosis and Management of Asthma. Bethesda, MD: National Heart, Lung, and Blood Institute.

NAEPP National Asthma Education and Prevention Program: Expert Panel Report III. (2007). Guidelines for the Diagnosis and Management of Asthma. Bethesda, MD: National Heart, Lung, and Blood Institute.

O'Byrne, P. M., Barnes, P. J., RodriguezRoisin, R., Runnerstrom, E., Sandstrom, T., Svensson, K., and Tattersfield, A. (2001). Low dose inhaled budesonide and formoterol in mild persistent asthma: the OPTIMA randomized trial. Am. I. Respir. Crit. Care Med. 164, 1392-1397.

O'Byrne, P. M., Pedersen, S., Busse, W. W., Tan, W. C., Chen, Y. Z., Ohlsson, S. V., Ullman, A., Lamm, C. J., Pauwels, R. A., and START Investigators Group. (2006). Effects of early intervention with inhaled budesonide on lung function in newly diagnosed asthma. Chest 129, 14781485

O'Byrne, P. M., Pedersen, S., Lamm, C. J., Tan, W. C., Busse, W. W., and START Investigators Group. (2009). Severe exacerbations and decline in lung function in asthma. Am. J. Respir. Crit. Care Med. 179, 19-24.

Paggiaro, P. L., Chanez, P., Holz, O., Ind, P. W., Djukanovic, R., Maestrelli, P., and Sterk, P. J. (2002). Sputum induction. Eur. Respir. J. Suppl. 37, $3 s-8$ s.

Papi, A., Canonica, G. W., Maestrelli, P., Paggiaro, P., Olivieri, D., Pozzi, E., Crimi, N., Vignola, A. M., Morelli, P., Nicolini, G., Fabbri, L. M., and BEST Study Group. (2007). Rescue use of beclomethasone and albuterol in a single inhaler for mild asthma. N. Engl. J. Med. 356 , 2040-2052.

Pauwels, R. A., Lofdahl, C. G., Postma, D. S., Tattersfield, A. E., O'Byrne P, Barnes, P. J., and Ullman, A. (1997). Effect of inhaled formoterol and budesonide on exacerbations of asthma. Formoterol and corticosteroids establishing therapy (FACET) International Study Group. N. Engl. J. Med. 337, 1405-1411.

Pauwels, R. A., Pedersen, S., Busse, W. W., Tan, W. C., Chen, Y. Z., Ohlsson, S. V., Ullman, A., Lamm, C. J., O'Byrne, P. M., and START Investigators Group. (2003). Early intervention with budesonide in mild persistent asthma: a randomised, double-blind trial. Lancet 361, 1071-1076.

Pearlman, D. S., van Adelsberg, J., Philip, G., Tilles, S. A., Busse, W., Hendeles, L., Loeys, T., Dass, S. B., and Reiss, T. F. (2006). Onset and duration of protection against exercise-induced bronchoconstriction by a single oral dose of montelukast. Ann. Allergy Asthma Immunol. 97, 98-104.

Peters-Golden, M., and Henderson, W. R. (2007). Leukotrienes. N. Engl. J. Med. 357, 1841-1854. 
Petsky, H. L., Cates, C. J., Lasserson, T. J., Li, A. M., Turner, C., Kynaston, J. A., and Chang, A. B. (in press). A systematic review and meta-analysis: tailoring asthma treatment on eosinophilic markers (exhaled nitric oxide or sputum eosinophils). Thorax doi: 10.1136/thx.2010.135574. [Epub ahead of print].

Petsky, H. L., Cates, C. J., Li, A., Kynaston, J. A., Turner, C., and Chang, A. B. (2009). Tailored interventions based on exhaled nitric oxide versus clinical symptoms for asthma in children and adults. Cochrane Database Syst. Rev. 4, CD006340.

Philip, G., Pearlman, D. S., Villarán, C., Legrand, C., Loeys, T., Langdon, R. B., and Reiss, T. F. (2007). Single-dose montelukast or salmeterol as protection against exerciseinduced bronchoconstriction. Chest $132,875-883$.

Phillips, M. (1997). Method for the collection and assay of volatile organic compounds in breath. Anal. Biochem. 247, 272-278.

Phillips, M., Herrera, J., Krishnan, S., Zain, M., Greenberg, J., and Cataneo, R. N. (1999). Variation in volatile organic compounds in the breath of normal humans. J. Chromatogr. B Biomed. Sci. Appl. 729, 75-88.

Phipatanakul, W., Nowak-Wegrzyn, A., Eggleston, P. A., Van Natta, M., Kesavan, J., Schuberth, K., and Wood, R. A. (2002). The efficacy of montelukast in the treatment of cat allergen-induced asthma in children. J. Allergy Clin. Immunol. 109, 794-799.

Pijnenburg, M. W., Bakker, E. M., Hop, W. C., and De Jongste, J. C. (2005). Titrating steroids on exhaled nitric oxide in children with asthma: a randomized controlled trial. Am. J. Respir. Crit. Care Med. 172, 831-836.

Polosa, R., Puddicombe, S. M., Krishna, M. T., Tuck, A. B., Howarth, P. H., Holgate, S. T., and Davies, D. E. (2002). Expression of c-erbB receptors and ligands in the bronchial epithelium of asthmatic subjects. J. Allergy Clin. Immunol. 109, 75-81.

Price, D. B., Hernandez, D., Magyar, P., Fiterman, J., Beeh, K. M., James, I. G., Konstantopoulos, S., Rojas, R., van Noord, J. A., Pons, M., Gilles, L., Leff, J. A., and Clinical Outcomes with Montelukast as a Partner Agent to Corticosteroid Therapy (COMPACT) International Study Group. (2003). Randomised controlled trial of montelukast plus inhaled budesonide versus double dose inhaled budesonide in adult patients with asthma. Thorax 58, 211-216.
Puddicombe, S. M., Polosa, R., Richter, A., Krishna, M. T., Howarth, P. H., Holgate, S. T., and Davies, D. E. (2000). Involvement of the epidermal growth factor receptor in epithelial repair in asthma. FASEB J. 14, 1362-1374.

Regamey, N., Ochs, M., Hilliard, T. N., Mühlfeld, C., Cornish, N., Fleming, L., Saglani, S., Alton, E. W., Bush, A., Jeffery, P. K., and Davies, J. C. (2008). Increased airway smooth muscle mass in children with asthma, cystic fibrosis, and non-cystic fibrosis bronchiectasis. Am. J. Respir. Crit. Care Med. 177, 837-843.

Röck, F., Barsan, N., and Weimar, U. (2008). Electronic nose: current status and future trends. Chem. Rev. 108, 705-711.

Roquet, A., Dahlén, B., Kumlin, M. Ihre, E., Anstrén, G., Binks, S., and Dahlén, S. E. (1997). Combined antagonism of leukotrienes and histamine produces predominant inhibition of allergen-induced early and late phase airway obstruction in asthmatics. Am. J. Respir. Crit. Care Med. 155, 1856-1863.

Royce, S. G., and Tang, M. L. (2009). The effects of current therapies on airway remodeling in asthma and new possibilities for treatment and prevention. Curr. Mol. Pharmacol. 2, 169-181.

Saglani, S., Payne, D. N., Zhu, J., Wang, Z., Nicholson, A. G., Bush, A., and Jeffery, P. K. (2007). Early detection of airway wall remodeling and eosinophilic inflammation in preschool wheezers. Am. J. Respir. Crit. Care Med. 176, 858-864.

Sampson, A. P. (2009). FLAP inhibitors for the treatment of inflammatory diseases. Curr. Opin. Investig. Drugs 10, 1163-1172.

Sandström, T. (2010). Effects of pharmacological and nonpharmacological interventions. Clin. Respir. J. 4(Suppl. 1), 41-48.

Selroos, O., Pietinalho, A., Löfroos, A. B. and Riska, H. (1995). Effect of early vs late intervention with inhaled corticosteroids in asthma. Chest 108, 1228-1234.

Shaw, D. E., Berry, M. A., Thomas, M., Green, R. H., Brightling, C. E., Wardlaw, A. J., and Pavord, I. D. (2007). The use of exhaled nitric oxide to guide asthma management: a randomized controlled trial. Am. J. Respir. Crit. Care Med. 176, 231-237.

Silkoff, P. E., Carlson, M., Bourke, T., Katial, R., Ogren, E., and Szefler, S. J. (2004). The Aerocrine exhaled nitric oxide monitoring system NIOX is cleared by the US Food and Drug Administration for monitoring therapy in asthma.
J. Allergy Clin. Immunol. 114, 1241-1256.

Smith, A. D., Cowan, J. O., Brassett, K. P., Herbison, G. P., and Taylor, D. R. (2005). Use of exhaled nitric oxide measurements to guide treatment in chronic asthma. N. Engl. J. Med. 352 , 2163-2173.

Sont, J. K., Willems, L. N., Bel, E. H., van Krieken, J. H., Vandenbroucke, J. P., and Sterk, P. J. (1999). Clinical control and histopathologic outcome of asthma when using airway hyperresponsiveness as an additional guide to long-term treatment. The AMPUL Study Group. Am. J. Respir. Crit. Care Med. 159, 1043 1051.

Sovijärvi, A. R., Haahtela, T., Ekroos, H J., Lindqvist, A., Saarinen, A., Poussa, T., and Laitinen, L. A. (2003). Sustained reduction in bronchial hyperresponsiveness with inhaled fluticasone propionate within three days in mild asthma: time course after onset and cessation of treatment. Thorax 5, 500-504.

Suissa, S., Ernst, P., Benayoun, S. Baltzan, M., and Cai, B. (2000). Lowdose inhaled corticosteroids and the prevention of death from asthma. $N$. Engl. J. Med. 343, 332-336.

Syslová, K., Kacer, P., Kuzma, M., Klusácková, P., Fenclová, Z. Lebedová, J., and Pelclová, D. (2008). Determination of 8-isoprostaglandin $\mathrm{F}_{2 \alpha}$ in exhaled breath condensate using combination of immunoseparation and LC-ESIMS/MS. J. Chromatogr. B Analyt. Technol. Biomed. Life Sci. 867, 8-14.

Szefler, S. J., and Martin, R. J. (2010). Lessons learned from variation in response to therapy in clinical trials. J. Allergy Clin. Immunol. 125, 285-292.

Szefler, S. J., Martin, R. J., King, T. S., Boushey, H. A., Cherniack, R. M., Chinchilli, V. M., Craig, T. J., Dolovich, M., Drazen, J. M., Fagan, J. K., Fahy, J. V., Fish, J. E., Ford J. G., Israel, E., Kiley, J., Kraft, M., Lazarus, S. C., Lemanske, R. F. Jr., Mauger, E., Peters, S. P., Sorkness, C. A., and Asthma Clinical Research Network of the National Heart Lung, and Blood Institute. (2002). Significant variability in response to inhaled corticosteroids for persistent asthma. J. Allergy Clin. Immunol. 109, 410-418.

Szefler, S. J., Mitchell, H., Sorkness, C. A., Gergen, P. J., O’Connor, G. T., Morgan, W. J., Kattan, M., Pongracic, J. A., Teach, S. J., Bloomberg, G. R., Eggleston, P. A., Gruchalla, R. S., Kercsmar, C. M., Liu, A. H. Wildfire, J. J., Curry, M. D., and Busse, W. W. (2008). Management of asthma based on exhaled nitric oxide in addition to guidelinebased treatment for inner-city adolescents and young adults: a randomised controlled trial. Lancet 372 , 1065-1072.

Szefler, S. J., Phillips, B. R., Martinez, F. D., Chinchilli, V. M., Lemanske, R. F., Strunk, R. C., Zeiger, R. S., Larsen, G., Spahn, J. D., Bacharier, L. B., Bloomberg, G. R., Guilbert, T. W., Heldt, G., Morgan, W. J., Moss, M. H., Sorkness, C. A., and Taussig, L. M. (2005). Characterization of within-subject responses to fluticasone and montelukast in childhood asthma. J. Allergy Clin. Immunol. 115, 233-242.

Takalo, R., Piirilä, P., and Sovijärvi, A. R. (2008). Repeatability of successive measurements with a portable nitric oxide analyser in patients with suggested or diagnosed asthma. Scand. J. Clin. Lab. Invest. 68, 830-832.

Taylor, D. R., Bateman, E. D., Boulet, L. P., Boushey, H. A., Busse, W. W., Casale, T. B., Chanez, P., Enright, P. L., Gibson, P. G., de Jongste, J. C., Kerstjens, H. A., Lazarus, S. C., Levy, M. L., O’Byrne, P. M., Partridge, M. R., Pavord, I. D., Sears, M. R., Sterk, P. J., Stoloff, S. W., Szefler, S. J., Sullivan, S. D., Thomas, M. D., Wenzel, S. E., and Reddel, H. K. (2008). A new perspective on concepts of asthma severity and control. Eur. Respir. J. $32,545-554$.

Tomlinson, J. E., McMahon, A. D., Chaudhuri, R., Thompson, J. M., Wood, S. F., and Thomson, N. C. (2005). Efficacy of low and high dose inhaled corticosteroid in smokers versus non-smokers with mild asthma. Thorax 60, 282-287.

Turpeinen, M., Nikander, K., Pelkonen, A. S., Syvänen, P., Sorva, R., Raitio, H., Malmberg, P., JuntunenBackman, K., and Haahtela, T. (2008). Daily versus as-needed inhaled corticosteroid for mild persistent asthma (The Helsinki early intervention childhood asthma study). Arch. Dis. Child. 93 , 654-659.

van den Toorn, L. M., Overbeek, S. E., de Jongste, J. C., Leman, K., Hoogsteden, H. C., and Prins, J. B. (2001). Airway inflammation is present during clinical remission of atopic asthma. Am. J. Respir. Crit. Care Med. 164, 2107-2113.

Vaquerizo, M. J., Casan, P., Castillo, J., Perpiña, M., Sanchis, J., Sobradillo, V., Valencia, A., Verea, H., Viejo, J. L., Villasante, C., Gonzalez-Esteban, J., Picado, C., and CASIOPEA (Capacidad de Singulair Oral en la Prevencion de Exacerbaciones Asmaticas) Study Group. (2003). Effect of 
montelukast added to inhaled budesonide on control of mild to moderate asthma. Thorax 58, 204-210.

Vignola, A. M., Rennard, S. I., Hargreave, F. E., Fahy, J. V., Bonsignore, M. R., Djukanovic, R., and Sterk, P. J. (2002). Standardised methodology of sputum induction and processing. Future directions. Eur. Respir. J. Suppl. 37, 51s-55s.

Villaran, C., O’Neill, S. J., Helbling, A., van Noord, J. A., Lee, T. H., Chuchalin, A. G., Langley, S. J., Gunawardena, K. A., Suskovic, S., Laurenzi, M., Jasan, J., Menten, J., and Leff, J. A. (1999). Montelukast versus salmeterol in patients with asthma and exercise-induced bronchoconstriction. Montelukast/Salmeterol Exercise Study Group. J. Allergy Clin. Immunol. 104, 547-553.

Walters, E. H., Reid, D. W., Johns, D. P., and Ward, C. (2007). Nonpharmacological and pharmacological interventions to prevent or reduce airway remodelling. Eur. Respir. J. 30, 574-588.

Ward, C., Pais, M., Bish, R., Reid, D., Feltis, B., Johns, D., and Walters, E. H. (2002). Airway inflammation, basement membrane thickening and bronchial hyperresponsiveness in asthma. Thorax 57, 309-316.

Ward, C., Reid, D. W., Orsida, B. E., Feltis, B., Ryan, V. A., Johns,
D. P., and Walters, E. H. (2005). Inter-relationships between airway inflammation, reticular basement membrane thickening and bronchial hyper-reactivity to methacholine in asthma; a systematic bronchoalveolar lavage and airway biopsy analysis. Clin. Exp. Allergy 35, 1565-1571.

Wenzel, S. E. (2006). Asthma: defining of the persistent adult phenotypes. Lancet 368, 804-813.

Conflict of Interest Statement: The author declares that the research was conducted in the absence of any commercial or financial relationships that could be construed as a potential conflict of interest.
Received: 23 May 2011; paper pending published:07 June 2011; accepted: 21 June 2011; published online: 14 July 2011. Citation: Montuschi P (2011) Pharmacotherapy of patients with mild persistent asthma: strategies and unresolved issues. Front. Pharmacol. 2:35. doi: 10.3389/fphar.2011.00035

This article was submitted to Frontiers in Respiratory Pharmacology, a specialty of Frontiers in Pharmacology.

Copyright (C) 2011 Montuschi. This is an open-access article subject to a nonexclusive license between the authors and Frontiers Media SA, which permits use, distribution and reproduction in other forums, provided the original authors and source are credited and other Frontiers conditions are complied with. 